\title{
LXVII. On the composition and origin of porcelain earth
}

\section{Henry S. Boase M.D.}

To cite this article: Henry S. Boase M.D. (1837) LXVII. On the composition and origin of porcelain earth , Philosophical Magazine Series 3, 10:62, 348-353, DOI: $10.1080 / 14786443708649169$

To link to this article: http://dx.doi.org/10.1080/14786443708649169

$$
\text { 曲 Published online: } 01 \text { Jun } 2009 .
$$

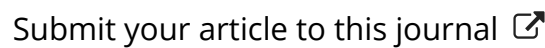

Џ Article views: 2

Q View related articles $₫$ 


\section{[ 348 ]}

LXVII. On the Composition and Origin of Porcelain Earth. By Henry S. Bonse, M.D., Secretary of the Royal Geological Society of Cornwall, \&c.**

HAVING lately seen in the Annales de Chimie et de Physique (tom. lxii. p. 225.) an interesting paper on Kaolin by Berthier, the conclusions of which, however, do not seem to me to be perfectly satisfactory, I am induced to offer a few remarks, together with an account of some experiments on the Cornish kaolin, in hopes of calling attention to this curious but complicated problen in "the chemistry of geology."

Berthier commences by observing that in a former analysis he found the kaolin of Limoges to be composed of

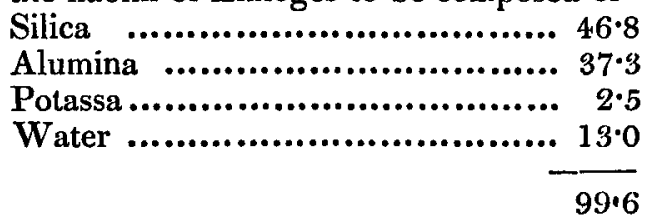

The presence of the alkali he attributed to a mixture of undecomposed felspar; and this being deducted, he considers that the remaining pure plastic clay is a silicate of alumina, represented by the formula $\mathrm{AS}+\mathrm{Aq}$, as also given by Forchammer for the porcelain earth of Bornholm. But by a recent set of experiments Berthier has found a considerable portion of magnesia in kaolin from various localities, as shown by the following analyses of the pure argillaceous parts, previously separated from the intermixed substances, by the successive application of sulphuric acid and of a solution of potassa.

\begin{tabular}{|c|c|c|c|c|}
\hline & Limoges. & Pamiers. & Elbogen. & Dept. de l'Allie \\
\hline Silica .......... & $.43 \cdot 05$ & $45^{\circ}$ & $61 \cdot 4$ & $56^{\circ}$ \\
\hline Alumina ...... & $\cdot 40 \cdot 00$ & $38^{\circ}$ & $23 \cdot 2$ & $37^{\circ}$ \\
\hline Magnesia ... & - $2 \cdot 89$ & $1 \cdot 2$ & 0.5 & much \\
\hline Water ....... & - $14 \cdot 06$ & $11 \cdot 7$ & $13 \cdot 8$ & $12 \cdot 3$ \\
\hline & $100^{\circ}$ & $95 \cdot 9$ & $98 \cdot 9$ & \\
\hline
\end{tabular}

These specimens of kaolin, with the exception of the first, do not appear to have been well prepared; indeed, even the clay of Limoges cannot be compared with that of Cornwall, since it contains from 20 to 25 per cent. of an undecomposed mineral; whereas the largest quantity which I have obtained from good Cornish samples is under 10 and as low as 8.5 per cent.

* Communicated by the Author. 
The substances which Berthier separated from kaolin are granules of quartz and minute white or yellowish-white scales having a pearly lustre. The composition of the scaly mineral he ascertained to be as follows:

Limoges. Pamiers. By calculation.

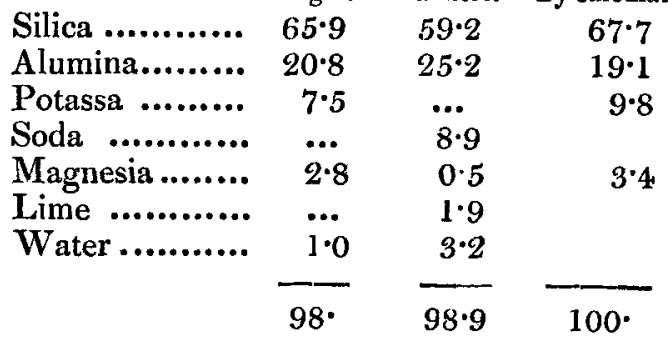

This mineral Berthier regards as the peculiar felspar from which the kaolin has been derived by decomposition. He has taken some pains to establish this point; and has attempted by calculation, founded on the above analyses, to give the true atomic composition of this supposed felspar. I am, however, inclined to think that he is mistaken: for the unaltered mineral which I have extracted from the Cornish kaolin is decidedly a variety of talc, in an extreme state of comminution, and its appearance under the lens exactly agrees with that described by Berthier. Now this mineral abounds in the talcose granite, or protogine, which by disintegration furnishes the beds of porcelain clay; but it does not experience any change, remaining in the clay, from which it is separated in considerable quantity during the process of preparation for the potteries. It seems to be nacrite or scaly talc of mineralogists, of which Vauquelin has given an analysis, nearly approximating to that of the scales from Pamiers as above quoted.

In denying that kaolin has been formed from the scaly mineral with which it is intermixed, I am willing to admit that it has been derived from a potasso-magnesian felspar which may be similar in composition to that indicated by Berthier's calculation. Indeed several years ago I suggested, on mineralogical considerations, that the felspar of protogine probably contains magnesia. This conjecture is now confirmed by the detection of this earth in kaolin; and I have since ascertained that it is also present in the china-clay of Cornwall.

The specimens examined were of the best quality from Breage and St. Stephens. The process which $I$ adopted was very similar to that employed by Berthier, and gave the fol. lowing results. 


\begin{tabular}{|c|c|c|}
\hline & Breage. & St. Stepher \\
\hline Silic & $40 \cdot 15$ & $39 \cdot 55$ \\
\hline Alümina.... & $36 \cdot 20$ & $38 \cdot 05$ \\
\hline Magnesia .......... & $1 \cdot 75$ & $1 \cdot 45$ \\
\hline Water............ & $11 \cdot 65$ & $12 \cdot 50$ \\
\hline $\begin{array}{l}\text { Insoluble residue } \\
\text { (quartz and talc) }\end{array}$ & $9 \cdot 50$ & $8 \cdot 70$ \\
\hline & & $\cdot 2$ \\
\hline
\end{tabular}

The circumstance most to be noted in all the analyses of kaolin hitherto made, is the great discrepancy in the results, which is unavoidable, because this substance is necessarily heterogeneous, quartz and talc being mixed with the silicate of alumina in variable proportions, even when washed with the greatest care. Berthier's process will show pretty nearly the quantity of silicate in the kaolin; but it includes two sources of error, for some alumina will escape between the scales of the talc, and some quartz will be dissolved by the alkaline solution. If, however, the earthy salt be completely separated, this does not indicate the actual composition of kaolin as an article of commerce, for the talc and quartz are not prejudicial to it; indeed protogine itself, under the name of china-stone, or petuntze, is ground and mixed with the porcelain-earth at the potteries.

I would also remark that the paper of Berthier, acceptable as it is as an analytical essay on an interesting subject, affords another instance of the great bias which the atomic system gives to reduce experimental numbers according to this Procrustean rule. Thus the kaolin is found to contain potassa; this is acutely referred to the presence of an unaltered mineral, proved by analysis to be the source of the alkali. But then its constituent parts, as obtained by experiment, are respectively drawn out or cut off, in order to suit the calculated composition of a potasso-magnesian felspar; and the evil has not stopt here, for the constituents of the kaolin are altered on the same data; and on these also it is attempted to explain the nature of the process by which kaolin is produced from felspar.

I now proceed to notice the perplexing problem concerning the formation of porcelain-earth.

Some have supposed this clay to be an original production, or rather a friable deposit from which the subjacent crystalline rock is now in progress of reconstruction. It is, however, at the present day generally admitted that it owes its origin to a chemical change effected in various kinds of felspathic rocks; but the precise nature of this change is yet unascertained. 
Werner was the first to attribute it to the action of water containing free carbonic acid, by which the alkali of the felspar is gradually abstracted. This opinion prevailed among chemists until Berthier showed that silica is also carried off dissolved in the alkaline solution, leaving a silicate of alumina, the constituents of which are consequently not in the same proportion as in felspar.

The late Dr. 'Turner has illustrated this subject in a very clear and pleasing manner, (Philosophical Magazine for July 1833, explaining the change by the following formula :

Felspar. Porcelain-earth.

$$
(\dot{\mathrm{Po}}+3 \dot{\mathrm{Si}})+(\underline{\mathrm{Al}}+9 \dot{\mathrm{Si}}) ;\left(\underline{\mathrm{Al}}+3 \frac{1}{2} \dot{\mathrm{Si}}\right) \text {. }
$$

The potassa is first set at liberty by the action of water and carbonic acid, and the composition of the felspar being thus subverted, the silica whilst in a nascent state is dissolved by the alkaline solution with which it is in immediate contact. "The formula," says Dr. Turner, "showed that every two equivalents of alumina present in porcelain clay along with three and a half of silica, corresponded in the original felspar from which it was derived, to twelve equivalents of silica and one of potash. Hence the quantity of silica carried off was enormous."

The process of decomposition from which kaolin results has also been well described by Fournet as quoted by Becquerel (Traité de l'Electricité et du Magnétisme, tom. i. p. 503), who has collected much interesting information on this subject.

“ ' Le feldspath, quand il est désagrégé et terreux,' dit M. Fournet, ... 'absorbe donc l'acide carbonique, qui réagit sur les silicates et s'empare de leur bases les plus fortes. La silice est mise en liberté à un état gélatineux qui lui permet de se dissoudre en certaine quantité, à la verité, dans les eaux et dans les carbonates alcalins; elle est alors entrainée par elles, et donne naissance, suivant les circonstances, à des cristaux de quartz hyalin, des fiorites, des agates, des opales, des concrétions calcédoines, et des silicates de nouvelle formation, telles que les mésotypes, les chabasies, \&c."”

These explanations are consistent with our present knowledge of chemistry; but they rest too much on induction, and not on actual experiment. For, in the first place, before the precise nature of the decomposition can be determined, it is necessary to ascertain the composition of the felspar; and I am not aware that this has ever been done. At all events, the felspar in the foregoing formula (which indeed is the one usually referred to on this subject) is the mineral which enters into common granite and not into protogine. And since these rocks occur passing gradually into each other in alternating 


\section{On the Composition and Origin of Porcelain Earth.}

series, not only in Cornwall, but also in the Alps and in the Vosges, and are situated under precisely the same circumstances, the fact that the one is decomposed to a hundred times the extent of the other would alone point at a difference in the composition of the felspar of the respective rocks. This is now, in some measure, established by the foregoing analyses of kaolin. It is, however, desirable that the felspar of the protogine should also be examined, though it will not be easy to procure a proper specimen for this purpose; and the chemist must be cautious in his selection of one, that he does not take it from the micaceous or shorlaceous granites with which the protogine is associated.

We have yet so much to learn concerning the properties of alumina and its combinations, that it is difficult to give a satisfactory account of the changes which occur even during the decomposition of common felspar. It is generally supposed that the alkali is first set at liberty and then acts on the nascent silica; but why not also on the alumina whilst in the same condition, or on the silicate of alumina, and still more on the alkalino-silicate of alumina, which is very soluble in alkalis and is most probably present in disintegrating felspar?

But supposing these difficulties surmounted, we have still the first and fundamental change to account for, viz. the subversion of the powerful affinity by which the constituents of the felspar are united. It is an easy matter to say that it is effected by the long-continued action of water and carbonic acid, but what is the modus operandi? In the laboratory, we cannot dissever the component molecules of this mineral by the most powerful acids; how then can the weakest effect it in Nature?

Berzelius has máde some excellent observations on this subject, (Traité de Chimie, tom. iv. p. 574,) instancing other substances, both natural and artificial, which resist solution in acids, contrary to what might be inferred from the nature of their composition; and he concludes that the elements of compound bodies do, in reality, combine in two distinct states of union.

Fournet, who has paid great attention to the difficult subject under consideration, is of opinion that the felspar must be first disintegrated (désagrégé) before the chemical action can commence; and he conceives that this is actually accomplished in consequence of felspar possessing the property of dimorphism, the new or second arrangement of the particles causing the disintegration. Becquerel justly remarks on this solution, that we have yet to learn that the particles of igneous rocks, on consolidation, did not assume a permanent form; and that they have experienced by the lapse of time a change 
in their arrangement. It may also be added, that if felspar be dimorphic, how comes it to pass that the granite (abounding in felspar) in which the protogine occurs is buts lightly altered?

It appears more probable that a difference in composition in the felspars of these rocks will afford the true solution of this problem, and though the data on which we can at present reason are very imperfect, yet $I$ am inclined to think that the presence of magnesia in the felspar of protogine may, among other causes, contribute toward the extraordinary change which this rock experiences. Thus, the magnesia may absorb carbonic acid, as well as the alkali, from the percolating water; and so great is its tendency to combine with two proportions of this acid, that even one part of the carbonate will attract the acid of the other, so as to pass into a bicarbonate of magnesia; in which state being soluble in water, it would be speedily removed. This in some measure explains the origin of kaolin, and it also accounts for the small quantity of this earth remaining in the porcelain clay; indeed I have examined some samples in which I could not detect a trace of magnesia.

This subject is one of great importance to the geologist, as affording an insight into a first and elementary step in the mighty changes which the crystalline materials of the globe have undergone; and the prosecution of this subject by chemists would confer a boon on geology, and at the same time cannot fail to be instructive to themselves by leading to a better knowledge of the combinations of alumina.

LXVIII. On Antimoniuretted Hydrogen, with some Remarks on Mr. Marsh's Test for Arsenic. By L. Thompson, Esq.s Member of the Royal College of Surgeons.

\section{To the Editors of the Philosophical Magazine and Journal.}

\section{Gentlemen,}

I BEG leave to direct the attention of your readers to a hitherto unnoticed combination of antimony and hydrogen, which acquires great interest from its near resemblance in many respects to arseniuretted hydrogen. The plan which I adopt for procuring this gas in its greatest purity is by fusing together equal weights of antimony and zinc, and acting on the alloy with diluted sulphuric acid; this process is not perhaps altogether free from objection, but answers very well for general purposes. As thus prepared antimoniuretted hydrogen is a colourless inflammable gas, exploding violenily by the electric spark or lighted taper when mixed with an equal volume of oxygen, chlorine, or atmospheric air ; its odour is Third Series. Vol. 10. No.62. May 1837. $2 \mathrm{Z}$ 